\title{
FROM THE 'DOMUS' TO THE 'SPECTACULUM': \\ FAMILY AND MARTYRSHIP IN EARLY CHRISTIANITY
}

\author{
Johannes N Vorster \\ New Testament and Early Christian Studies \\ College of Human Sciences \\ University of South Africa
}

\begin{abstract}
Early Christian martyr discourse combines two discursive practices, namely that of the household and the spectacle. How and why these practices are used in martyr discourse is enquired from the perspective of the dominance and pervasiveness of Roman normative culture and its formative effects on emerging early Christianity. Two martyr narratives namely the Passion of Perpetua and Felicitas and the Martyrs of Lyons are analysed to determine how household discourse has been integrated into the framework of the spectacle.
\end{abstract}

Key Words: Early Christian Martyrdom, Early Christian Household, Roman Family, Domus, Perpetua and Felicitas, Martyrs of Lyons

\section{Introduction}

In his study on radical martyrdom, Middleton poses the question why the early Christians chose agonistic discourse in their depiction of their arrests, trials and interrogations. According to him it was because their martyrdom was seen as a 'cosmic contest' (2006:79). A distinction should of course be made between the martyr narratives and the torturing as punishment to which these writings refer. The martyr narratives undoubtedly function within the framework of the agonistic, and in many cases a totalitarian, mythological appeal is made to 'cosmic' battle. But does an acknowledgement of their claims really provide with a clarification for the use of agonistic terminologies? Does the competitive angle which Middleton has recognised not derive from exactly similar rules of the game? Agonistic discourse undoubtedly plays a role, but are more discursive practices not simultaneously at work in the making of early Christian identity? How and why can a criminalised, tortured early Christian woman be called a 'noble athlete,' but also a 'wife (matrona) of Christ'? And why do these types of references abound in martyr discourses?

In this article I illustrate how domestic and spectacle discourses jointly functioned in the construction of early Christianity. I argue that early Christianity availed itself of Roman normative culture and that similar processes at work in Romanisation, also functioned in the processes of Christianisation. Enquiring domestic discourse as it has been used within the framework of the Roman 'games' allows to see how social hierarchies have been retained, and how Roman social order and early Christian social order were instructed by the regime of the phallus.

In the first section the two discursive practices domus and spectaculum are juxtaposed and an attempt is made to demonstrate how they have been produced from the same 
regulatory ideals. In the second section two martyr narratives are analysed, namely The Martyrs of Lyons deriving from Gaul, referring to a situation during $177 \mathrm{CE}$. The second narrative, The Martyrdom of Perpetua and Felicitas refers to a situation in North Africa, Carthage in the year $203 \mathrm{CE}$. Although it would have been possible to focus on more aspects in both these narratives, attention has predominantly been given to the martyrships of two women, the slave Blandina and the freeborn, noble Perpetua, since their representation in the narratives allows for a more clear view on identity generating strategies at work.

\section{'Domus' and 'Spectaculum' in the Roman Empire}

During the first three centuries of the common era, two discursive practices, namely that of the household and the spectacle, acquired particular prominence as mechanisms for the establishment of social order and creating cultural identity in the Roman Empire. Within the hands of the imperial regime, both practices functioned as sites for the cultivation and maintenance of normative, cultural values operating in the production of 'Romanness.' Parker (1999:163), in referring to the hierarchical space of the theatre, aptly describes it as 'an embodiment of Rome,' and he continues to depict it as follows: "The theatre, with its huge and encoded crowds, becomes a synecdoche for Rome itself” (1999:163). Given a constant, imposing presence, not only with its impressive architectural design, but also with its intrusive noises, its smells, the elaborate processions, it exuded dominance, glory, the potential and the magnanimity of the powerful. Huge amounts of money were spent on hosting the 'games,' ${ }^{1}$ careers of the ambitious Roman elite leapfrogged ahead ${ }^{2}$ in presenting spectacles and the required presence of the Emperor, his visibility, lavishness and omnipotence over life and death, ${ }^{3}$ celebrated the superiority of Romanness. Arranged in an enclosed space, ${ }^{4}$ restricted to a particular duration, repeated at regular intervals, ${ }^{5}$ the crowd was reminded of battles, deriving from a violent, but glorious past (Hopkins 1983:29), that made their present possible and validated their claimed superiority. This was a place where punishment penetrated the interior of the body, exposing its recessive areas to the gaze of aloof, Roman civic order, ${ }^{6}$ demonstrating at the same time the product of resistance against the Emperor $(1983: 15,29)$. Forces, forcefully concentrated by space and time, functioned in the formation of a Roman collectivity, that found its subjectivity in phallocratic manliness. ${ }^{7}$ The main reason for the investments and sacrifices made for the maintenance and cultivation of this practice was the preservation of Roman social order via the production of cultural identity. Bergmann (1999:23) states that the "spectacles were the chief means for creating cultural identity in Hellenistic and Roman societies."

1 Examples of the cost involved, as well as of the problems to curb both the costs and elite ambition, see Hopkins (1983:7-14).

2 Hopkins (1983:12-13) shows that in both Rome and the provinces gladiatorial shows "were produced by leading citizens as a tax on status, at once an obligation and an opportunity for self-enhancement."

3 See Hopkins $(1983: 16,18,19)$.

4 For a description of the Roman theatre as a reflection of social hierarchies and the values assigned to these hierarchies, see Parker (1999:164-165).

5 See Bergmann (1999:23) indicates how the calendar, the urban topography and the architecture of the particular spectacle created 'a separate, mimetic world ' which had a profound, differentiating effect on the type of attention given to the event.

6 Gleason (2002:300) writes: "The effect on the victim was the simultaneous destruction of his (sic) physical autonomy, of his sense of social connectedness, of his subjectivity altogether," and a bit further: "[P]ublic violence... effects a forcible realignment of subjectivity to identify with the enforcing power."

See also Parker (1999:166,175). 
But were they? Were the spectacles, the 'chief means' for the production of cultural identity? Despite the profound effect the spectacles may have had in the maintenance of social order through the making of cultural identity, can they be given this predominant, creative position in the making of culture? Despite its representation in a wide variety of genres, whether that be literary, imagery, sculptural or architectural, assigning the spectacles 'chief' position, precludes other discursive practices that were also summoned in the making of Romanness. One of these was the household.

Just as spectacle discourse, domestic discourse also functioned in the process of romanisation, and just as the spectacle served to maintain and cultivate social order, the Roman household, despite its various instantiations, functioned as site of stability in upholding Roman social order. Treggiari $(2003: 132)$ reminds that the "[G]reek and Roman theorists saw marriage and the procreation of children as fundamental to human society." Although marriage and the raising of a family should not always be assumed as the desirable option in antiquity and was, for example, problematised, but not rejected by later Stoicism (Gace 2003:87-93), the family was seen as a microcosm of a larger political macrocosm by means of which social control could be implemented. As a matter of fact, the conventional view configured a harmonious, natural relationship between 'the pair,' their 'offspring,' their 'house and all things common to them,' the 'city' and the 'state' (Treggiari 2003:144). ${ }^{8}$ The household was seen as a 'sort of constitutional monarchy' with the paterfamilias (head of the household) as absolute ruler, having power over the life and death of the members of his household by virtue of what was called patria potestas. ${ }^{9}$

It was especially during the imperial period that the family acquired prominent status as discursive practice. It should be borne in mind that the numerous wars conducted by the great generals of Rome extended and expanded the boundaries of the Roman nation considerably, allowing for an influx of non-Romans in search of status and wealth. Decades of war had changed the demographics of Roman society and a new political dispensation was gradually appearing on the horizon, changing not only the constitution of Rome's social hierarchies, but also increasing the power of the Emperor while at the same time decreasing the power of a body, such as the senate.

It has also been argued that these socio-political changes had a profound effect on the notion of family, which can be seen in changing valorizations of familia and domus (household). According to Saller (1984) the notion of familia was gradually marginalized in favour of the notion of domus during the imperial period. Although the notion of the familia never disappeared from the social scene, the term domus was more appropriate during the imperial period. Prior to the imperial period, familia was used to signify agnatic lineage, that is, blood relationship through males, not including females. The children could therefore belong to the familia of the father, but the mother herself was not part of that family, still subject to the potestas of her paterfamilias. The notion of domus was much wider and this term could include the "physical house, the household, including family and slaves, the broad kinship group including agnates and cognates, ancestors and descendants, and the

\footnotetext{
Treggiari (2003:145) quotes Cicero who stated: "Because the urge to reproduce is an instinct common to all animals, society originally consists of the pair, next of the pair with their children, then one house and all things in common. This is the beginning of the city and the seedbed of the state."

9 The phrase patria potestas could be translated as 'the authority of the father.' However, the translational equivalent 'authority' lacks the component of absolute control this provision catered for. More correct would probably be 'fatherly dominion.'
} 
patrimony" (1984:342). ${ }^{10}$ The effect of this gradual change was that those belonging to the upper echelons of imperial Roman society could no longer "boast a long, illustrious agnatic lineage" and the need for a great nomen (family name) also dwindled (1984:349). Owing to changing relations of power, the term domus, which in any case was a symbol of power and status, was foregrounded during the imperial period, but instead of signifying lineage, its reference to status was infused by the 'current wealth and power of the owner' of the household (1984:351). ${ }^{11}$

The wider scope which is opened by the term domus, made it suitable and convenient as symbolising status and power. There was for example, a particular sanctity to the site of domus. Not only was it used as reference to the temples and altars of divinities, but this was also the site where the household gods were accommodated. When the generals of Rome departed they appealed to their soldiers to fight for patria domusque (fatherland and home). A man's home was his last refuge (perfugium sanctum; 1984:350) and when a Roman citizen was scandalized and killed, his house was erased to the ground. ${ }^{12}$ If the notion of domus then, was differently valorized during the imperial period, and if a person's house signified status and honour, and if a close identification existed between house and owner, the household becomes a distinctive constituent in the construction of identity, especially when the physical house also provided with the opportunity to evoke via imagery symbols of collective identity.

It was, however, also during the imperial period, especially during the first three centuries, that the romanisation programme extensively exploited and used domestic discourse. Put somewhat differently: Rome's policies of domestication served romanisation. Although difficult to gauge the real effects of Augustan matrimonial legislation, promulgated by the lex Iulia de maritandis ordinibus, the lex Iulia de adulteriis in $18 \mathrm{BCE}$ and the remedial lex Pappia-Poppaea (9 CE), these laws reflected a change in the valorization of the family. The first law regulated (in a restricting sense) matrimonial relations between the classes, as well as encouraging reproduction among the elite by regulating patrimony, and offering possibilities of emancipation. The second law criminalised adultery among the elite. These laws were clearly promulgated for the purpose of quality control, but the need for quality control emerged from a recognition of the family as strategy in the making of Romanness. Their significance lies less in their effect and intention, than in the motivation to publicly integrate the strategies of honour and shame accommodated by the Roman household, while at the same time also control and regulate not only the interiority of the family, but also exploiting its qualities of stability, fixity and hierarchy to construct and edify Romanness. Besides these laws, and confirming Augustan exploitation of domestic discourse, a very deliberate programme of depicting the Roman nation as family with the Emperor's family as model, and the Emperor as pater patriae, was followed in a variety of media. Owing to the absolute power of the paterfamilias, granted by virtue of the patria potestas, Roman matrimonial order, existing in the modi of domination and submission, was not only

10 The relationship between familia and domus is more complicated than space allows for a more comprehensive explanation, not only because a distinction should be made between legal and colloquial usages, but it also involves related notions such as manus referring to a transition from the potestas of the wife's paterfamilias to the potestas of her new husband. A transition, (just to complicate matters further), which did not always coincide with entry into matrimonial status (see for example Treggiari 2003). Late antiquity introduced further modification as indicated by Cooper (2007).

11 The situation is again more complicated as can be seen by the cautious note of Saller (1984:351 note 56).

12 See for example Cicero's views on how a house bestows status, and also the destruction of his Palatine domus as presented by Hales (2000). 
caught up in the supreme reign of the phallus as cultural signifier but served also to perpetuate and politicise phallocraticism.

It was therefore during the same imperial period that two discursive practices forcefully participated in the construction of Roman cultural identity. Apparently these two discursive practices appear as if independent, if not opposing. If for the moment the invalid distinction between public and private may be used, the notion of domus belongs to the sphere of intimacy and privacy, whereas the spectaculum strives towards the complete destruction and inversion of the private to the extent of opening the inside of bodies; the domus as the sphere where birth gives to life and is succeeded by growth in an environment of nurturing and security, whereas the spectaculum signifies death and the disintegration of the body by extended and continuous torture. Yet it is exactly in this interplay between the domus and the spectaculum that the dichotomy between public and private is rendered illusionary, because these two discursive practices functioned, not parallel and disjuncted, but in constant transgression of purported boundaries.

On the one hand, the space of the household was invaded by and intruded upon spectacle discourse in both literary and material sense. I have already referred to the manner in which the processions, the cacophony of noises and the propaganda for the games must have made its presence felt, also within the security of the house. Owing to the status of this practice, spectacle was also represented by imagery in the house, utensils and ornaments. Brown (1992:181) reports that the various types of gladiatorial and venatorial combatants were found to be represented on "lamps, ceramics, gems, ivories, funerary reliefs... architectural reliefs, wall paintings and floor mosaics." Chariots and gladiators entered Roman houses even on coins, as can be seen by a golden coin from the time of Septimus Severus (206 CE; Bergmann 1999:25). Brown elaborates on some of the extant floor mosaics depicting a wide variety of contests in the arena (1992:187-207). Standardization of games imagery was customary although adapted to the idiosyncracies of the patron's requests, which is an indication of the popularity of these scenes in the houses of the Roman elite in both Rome, the western and North African provinces (1992:187). ${ }^{13}$ Within the houses of the elite, these mosaics usually served as decorative material in the public rooms, such as "peristyles, corridors, and the Roman-reception-cum-dining rooms" (1992:188), thereby performing as status indicators. If it is taken into consideration that status is constructed by brutal violence, by a constant play on the acts of domination and submission, the naturalness with which phallocraticism regulated the everyday lives of the Roman citizen and maintained social hierarchies become understandable. If it is taken into consideration that the customary connotation attached to the participants in the games were usually that of infamia (dishonour and disgrace), its repeated representation in different media, entering the homes of Roman citizens, served as a constant reminder of phallic regime, of male domination and effeminate submission. Parker (1999:166) aptly describes as follows: "Ultimately at the base of this cultural symbolism is the image of the idealized male body and the category Woman. The male is active, the female passive. The male is the penetrator, the female the penetrated... Thus, for the Romans, the gaze is male," for the paterfamilias a constant reminder of his potestas, his control and dominion over the 'others' in his house, for the civis Romanus a constant reminder of the superiority of the family of the Roman nation, acquired by active, impenetrable manliness.

13 Floor mosaics were the penchant of the affluent, while figurines, ceramics and lamps were the media upon which contests were displayed for the benefit of the masses. 
Separating domestic or familial discourse from the discourse of spectacle may be logical for contemporary interpretation, but for the Roman citizen both these sites were determined by the same system of values. Violence and cruelty were differently constructed and found a home in both spectacle and house. Hopkins repeatedly emphasises the violence of Roman culture. ${ }^{14} \mathrm{He}$ writes (1983:28): "Rome was a cruel society. Brutality was built into its culture, in private life as well as in public shows. The tone was set by military discipline and by slavery, to say nothing of wide-ranging paternal powers." The ethos of domination that was valid for the spectacle, also permeated the domus via the absolute control granted to the paterfamilias by virtue of his potestas. This control allowed him to decide whether an infant should be raised from the ground or left to die. He had the right to demand a divorce on behalf of his son or daughter even against their wishes or his spouse's; he was also allowed to kill his daughter and lover if caught in the act of adultery; ${ }^{15}$ he determined whether emancipation of his children and of his slaves should take place, and he controlled what they and his wife will inherit. In addition, in a form of structural violence, social hierarchies were rigidly enforced in the household. Though slaves were part and parcel of the household, and were even integrated into the education of a Roman citizen's children, their level of social existence could be equated to that of animals. No right to any bodily integrity was available for them. They could be whipped, could be branded, could be sold and could be used as sex objects. This does not mean normative Roman household culture was only violent. There is abundant evidence that there were also counter voices and practices, such as emancipation, an aversion to uncontrolled anger concerning slaves and members of the household, just as clemency was sometimes showed in the amphitheatre, and a censuring of certain behaviours in the amphitheatre. But the default, the logic that determined and regulated conduct and practice stemmed from a predisposition toward, phallic domination and control, irrespective of the site of emergence.

It was during this period in the history of the Roman Empire, when both domestic and spectacle discourse were at their heyday, and when both these discourses functioned as strategic mechanisms in the construction of Roman identity, that early Christian martyr discourses originated. To an extent it was inevitable that early Christian martyr discourses would have permitted household discourse to enter the site of the games. The configuration of Emperor cult, emperor as pater patriae, sanctioned by the ultimate and absolute potestas, regard for social marriage and household life as one of the cornerstones of Roman order, the particular period in which romanisation was to be achieved via domestication, implied that resistance to one component of this configuration adversely also affected the rest. To deny the emperor sacrifice was to threaten and insult the Roman nation as household. To show a disregard for marriage and domus could not be taken as a particular individual preference, nor as simply the expression of a belief system, but could only be seen as an attempt to contaminate Roman social order and a threat to Roman identity whose glorious past was indebted to this institution. What exactly prompted the integration of domesticated discourse in the martyr discourse still requires further enquiry, but what will be shown is how domestic and spectacle discourse, derived from normative Roman culture, simultaneous and jointly, collude and dispute in the formation of early Christian identity.

14 It is as if Hopkins cannot sufficiently emphasise the violence of Roman society. He describes Rome as a 'warrior state' (1) the amphitheatre as 'artificial battlefields' (2), gladiatorial contests as approximations of 'human sacrifice' (5), the games as a 'status bloodbath' (9), a 'militaristic society' (29). And yet it was in this cruelty that their moral order was reaffirmed (29).

15 See Hopkins (1983:244), also note 58. 


\section{Domus and Spectaculum in Early Christianity}

\section{The Martyrs of Lyons}

Presented in the form of a letter, no clear movement from domus to trial is given. Instead the introductory section integrates the entire incident within the setting of a mythological battle in which the 'Adversary' is seen as the real opponent. How the familial enters this field must therefore be constructed.

Already in the introduction mention is made that the martyrs were actually excluded from their houses, from the baths and the public square, from which it can be inferred that early Christians were prohibited to convene in any place $(1.5) .^{16}$ The charge trumped up against the Christians of Lyons, derives from familial discourse, demonstrating the stability of Roman social hierarchies, also within the domus, as point of departure of the narrative. This does not mean that this stability was de facto the case, but it does allow to argue for a positive valorization of familial practice among Christians during this period. Familial discourse functioned within a rhetoric of blame or praise and in the case of the early Christians in Lyons, it served to vilify by accusing them of incestuous and cannibalistic practices (1.14). ${ }^{17}$ However, the writing presents this charge as wrung from the non-Christian household slaves in the households of the Christian martyrs (1.14). When these slaves saw how the 'holy ones' were tortured, they became afraid and accused their owners of hideous crimes. Owing to the negative social valorization of slaves, namely as made from a 'naturally' inferior substance, slaves were seen as prime targets for interrogation under torture, since, deriving from the sphere of the dishonourable, they were regarded as by default disloyal and a constant threat to their masters (see also Parker 1998:155-156; Callahan and Horseley 1998:140-147). ${ }^{18}$ Prevailing social hierarchy in which slaves were represented as prone to the betrayal of their owners is evoked but here as critique on the reliability of the charge against the martyrs, illustrating early Christian collusion with normative, cultural, domestic hierarchies. The qualification ethnikoi should not be underestimated. Parker has shown to what extent slaves should be seen as occupying 'outsider' status. ${ }^{19}$ Although regarded as part of the household under the potestas of the pater, ${ }^{20}$ they lacked 'natural' kinship, and though linked to the household they were the 'complete outsider' (1998:154). Socially they were completely neutralised, with no recognised parents, incapable of marriage, and their children as the possessions of their master. As a result they were also seen as 'morally incapable of social relations' (1998:155). Parker (1998:155) writes: "They were seen as ignorant of pietas..., lacking in fides..., and imbued with treachery, imperilling

16 The Christians were probably forbidden to convene. Although three sites are here referred to, that houses functioned as site of assembly can also be seen in the Martyrdom of Polycarp 5.1, 6.1, 7.1, 20.2; The Acts of Justin and companions, A.3.1 and 3.3 (in the latter also the reference to a dwelling place above the baths, despite the corruption of the exact name in the manuscripts (see Musurillo 1972:44,45); B.3.1-3; C.3.4; The Martyrdom of Pionius the Presbyter and his companions, 2.3; The Martyrdom of Saint Conon, 1.3. The prohibition not to be seen anywhere probably addressed the claim of Christians that their abode is not to be restricted to a particular site.

17 Whether the charge conjured in 1.14, namely Oedipean marriages and Thyestian dinners, was in fact launched against the martyrs of Lyons is not at issue. Neither does a harmonising with Tertullian who also mentions this charge as possibility, allows for an interpretation claiming historicity - see Tert. Apol. 7 .

18 See also Pliny the Younger, Ep. Tra. 10.96.

19 It can be translated with 'gentile,' or 'pagan,' but it is a question whether these translational equivalents express the specific quality of political exclusion and downgrading. Perhaps 'foreign,' or 'outlandish' would have been more appropriate.

20 Patria potestas as the authoritative, controlling, patrilineal dominion of the oldest living male member of the household. 
their master's very life." Qualifying this inferior social category with ethnikos from an early Christian perspective is to increase the position of inferiority, to 'double' their outsider status, thereby maintaining Roman social hierarchicalisation, but portraying non-christianized slaves as even more unreliable. ${ }^{21}$

The qualifier ethnikos functions also to anticipate another differentiation, namely the christianized woman slave, Blandina. Her introduction confirms again that the Roman socio-cultural hierarchies with its deep seated prejudices and anxieties remain intact in this writing. Blandina functions as an example of how a slave regarded as worthless, formless and contemptible can bestow honour on her master, which is in this case described as Christ (1.17). By her loyalty to him, she is portrayed as a slave transforming what could be regarded as ministerium (service), that is, her conventionally required servitude, into beneficium (benefit), that is, being of benefit to her master by bestowing honour on him through her loyalty in action. ${ }^{22}$ However before the actual torturing process commences in the narrative, Blandina's mistress, herself a martyr doubts whether Blandina would be able to endure her ordeal and make a confession owing to the natural disposition of slaves towards weakness of the body (1.18). Blandina will indeed be portrayed as exceptional, but the premise of the narrative is the 'natural' inferiority of the slave's body.

Never departing from her status as slave, Blandina proves to be a very loyal slave, and the degree of her voluntary endurance approximates that of her master, Christ (1.41). With some of the other male and freeborn martyrs she is described as a 'noble athlete' (1.18), reflecting that 'mighty and invincible athlete' (1.42); she is hung on a post 'in the form of a cross' (1.41) and in exemplary fashion her co-sufferers 'saw, in the person of their sister, him who was crucified for them' (1.41). Yet, typical of the exemplum of the loyal slave, her status of slave does not disappear - what makes her endurance so remarkable is that it is least expected from her as a slave. It was as 'tiny,' 'weak,' and 'contemptible,' that she functioned as an example for her 'brothers' (1.41).

In a third and final appearance of Blandina in this martyr narrative (1.53-56), she is brought into the amphitheatre on the last day of the gladiatorial fights, accompanied by a boy, Ponticus, of 15 years (1.53-54). Domestic discourse functions to radicalise normative, Roman cultural hierarchies. In this scene she is compared to a 'noble mother' who is prepared to have her sons sacrificed in battle and who is herself prepared to follow in their wake (1.55). And the voluntariness with which she awaits her fate attacked by animals, in particular a bull, is compared to an invitation to a bridal banquet. Depicting her as the 'noble mother' encouraging her children, she resembles exactly the stern matrona, in whom the moral authority resided to raise disciplined sons, while their fathers were away at war, an ideal bemoaned by poets, such as Horace to be grossly incongruent with the daily practice of the imperial period (Skinner 2005:205). The subtle erotic overtones referring to her 'intimacy ${ }^{23}$ with Christ,' whose household she benefits, in the description of her death, comes as no surprise (1.56).

Normative Roman cultural values have been embodied in a female slave, set within their given social hierarchies. That the body of a female slave has indeed been used points to a shuffling in the valorization of household values, but this shuffling-shifting is not to

21 Parker (1998:164) also refers to Appian, Bell.civ. 4.15 where it is clearly implied that any goodwill of slaves towards their masters is hyper physin, beyond their nature.

22 See the excellent essay by Parker on 'tales of loyalty' in which slaves function as exempla and through proving their loyalty change ministerium into beneficium. Parker uses Seneca's Benefits 3.18.1 as framework for the analysis of these exempla.

23 The lexeme homilia can also be translated as sexual intercourse. 
oppose with a different set of values, but to take prevailing values to its extreme and expose the inconsistencies of the Roman nation via the consistent abiding of the emerging Christian nation.

I have spent more attention to Blandina because her integration into this narrative closely demonstrates how early Christianity used household discourse to illustrate how the household of Christ continues and radicalises existing, normative cultural values. Blandina is not the only example of the use of familial discourse in this narrative. In making a distinction between those Christians who opted for martyrship and those who did not, the latter is described as 'stillborn' (1.11) which implies that avoiding martyrship, meant also complete exclusion, annihilation from the Christian family. Only those who opted for martyrship obtain 'insider' status, described in the intimacy of family discourse. When this distinction is carried further in describing how these deniers were not only also tortured, degraded to the status of criminals, taunted by the crowd owing to their cowardice and suffering from a guilty conscious, the empowering effect of belonging to and being sustained by the 'family' is confirmed (1.35). However, the cultural aversion towards the coward is evoked to stigmatize and vilify the deniers. They are contrasted with those who did not deny their faith and despite of being tortured carried themselves joyously as 'a bride... exuding... the sweet odour of Christ. ${ }^{24}$ Although there may be sacrificial connotations hovering in the background, the reference to scent in this instance should probably be understood in an aesthetic sense (Harvey 2006:47), which serves to enhance the social status of the martyrs. ${ }^{25}$ However, those Christians who did not confess Christ are described in terms of the rejected woman - they are 'dejected,' 'humbled,' 'ugly,' and completely 'lacking any form' (1.35). ${ }^{26}$ To add to their misery, they are insulted by the crowd as of 'low birth,' 'manless,' and 'homicidal,' because they have shunned the 'life-giving name.'27 A little later in the narrative, they are again excluded when they prove themselves to be consistent in their denial, not even having 'any knowledge of the wedding garment,' actually being 'sons of perdition' (1.48). Domestic discourse demarcates into coward, effeminates, belonging to the outsiders, and noble, brave, enduring bride given status owing to her intimacy with Christ as insiders.

Domestic discourse in the guise of birthing terminology serves to allow those that have defected to return (1.45:49). 'Giving birth' as part of familial discourse, suggesting initiation into the family of Christ, is used when the example of the martyrs functions mimetically in restoring the deniers to life. The martyrs, especially their 'endurance,' function as agency, allowing for Christ's favour to bring the deniers to life via an inversed birthing process. The 'virgin mother' rejoices in this reversal of abortion, and the deniers in a retracing of the birthing process are 'conceived again and rekindled and learned to confess Christ.' Quite explicitly is the empowering effect of the re-birthing process conveyed when their appearance before the tribunal is described as 'alive now and strengthened.'

The metaphor of 'giving birth' is again used in the case of Alexander, albeit in a different sense. Encouraging those who denied to confess, he is described as 'one who suffers the pain of giving birth'. The manner in which only what woman in the reproductive

24 Musurillo's 'exhaling' ignores that they have been smelt by those around them.

25 See Potter $(2002: 175,177,179)$; on the perfuming of theatres and amphitheatres (see 178). The concern here is neither incense, nor sacrificial, since it is associated with the 'bride.' As such it portrays the martyrs as of higher social standing.

26 See Carson (2002:79) on the representation of women as formless content owing to their inherent, natural moistness, and the manner in which this became common place through myth.

27 I have deviated here from Musurillo's translation which ignores the engendered connotations of the passage. 
process can do, is usurped should not go unnoticed, because despite of the role assigned to Blandina and despite of the use of matrimonial terminology in which the martyrs are portrayed in the role of the bride or the mother, familial discourse functions as stage for the display of radicalized, Roman, normative, engendered cultural values. The prevailing, existent engendered social hierarchies have not been suspended, but have instead been appropriated by early Christians to demonstrate their superiority.

\section{Perpetua and Felicitas}

Few martyr narratives so vividly portray the movement from domus to spectaculum as the Passio Sanctarum Perpetuae et Felicitatis which refers to events that probably took place on 7 March 203 on occasion of Geta's birthday, who was the son of Septimius Severus (Shaw 1993:3; Ronsse 2006:286). The place was Carthage, renowned for its growing importance as North African city, visible also in its public architecture, such as the Antonine Baths, a theatre, circus, odeon and amphitheatre (Bomgardner 1989:85). It was the time of an emerging Montanism, the presence of a Tertullian, and an imperial aversion of superstition, magic and the insistence on dreams and visions as reflections of reality (Wypustek 1997)... all aspects encountered in this martyr narrative. We encounter Perpetua as already under arrest (3.1) once an introductory argument has been conducted why this present example of faith should also enjoy the status of truth and authority usually assigned to ancient accounts (1.1-6).

However, the prison as scene abounds with allusions to the domestic situation. In the Latin version Perpetua is not 'bundled into' or 'thrown into' prison as in the Greek, but they are 'welcomed,' lodged in prison (Heffernan and Shelton 2006:220;3.5), ${ }^{28}$ and the scene of the prison is gradually turned into not only 'home' but into what can be called the 'official residence of the praetorius,' that is the praetorium (3.9). ${ }^{29}$ A shift has taken place in terms of Roman 'architectural' hierarchy, from prison as ultimate institution for excluding threats to imperial dominant discourse, to praetorial house, affirmative symbol of imperial regime. The prison has been domesticated via one of the roles allocated to the Roman wife, namely to care for her children. ${ }^{30}$ The domestication of the prison, the transformation from a dwelling of the devil to a place of liberation and safety is a theme we also encounter in Tertullian's Ad Martyras (2.1). ${ }^{31}$ With him domestic discourse functions trans-

28 There is also the vague connotative reference in the verb recipere to 'take to oneself,' or 'receive' and in conjunction with gladium (sword), or ferrum (metonymical use of iron for sword), it could mean to 'receive the death wound'(Cassell's New Latin Dictionary 1969:508), thereby a subtle anticipation of what would constitute Perpetua's end.

29 How Heffernan and Shelton (2006:222) can find something 'deeply suggestive of her hope for a paradise-like refuge' in the narrative boggles the mind. What is at stake is a problematization of Roman social order; space allocated specifically for the 'outsider' turns into what can be regarded as quintessentially 'insider' space, that which functioned as ideal.

30 Care should be taken not to impose modern, Western notions of affection on to the relations between parents and children. One of the conditions determining parental relations of affection was the high percentage of infantile deaths, as well as the relative short average life-cycle of 25 to 30 years. Hanson (1999:46) writes: "Life was as precarious as it was precious, and those who were the survivors found themselves ever in the midst of death and dying, for people of all ages perished at a rate no longer known in the modern democracies of the Western world." This simple demographic fact probably also gave rise to the practice of handing the child over to a wet nurse for a short period after birth, and may also explain why the need for physical bonding between child and parent was not that prominently manifested in antiquity (Hanson 1999:36-37).

31 The portrayal in The martyrdom of saints Perpetua and Felicitas of the martyrs's stay in the prison almost appears as a concretisation, an example of Tertullian's musings on the prison. 
formatively in its invasion of the "penitentiary. ${ }^{32}$ On the one hand it serves as the site where alternative family ties are fashioned and consolidated; on the other hand, it also functions as site where traditional family relations can be problematized. ${ }^{33}$

When Perpetua and her fellow martyrs are introduced, she is situated within familial discourse and her relatively high social status can be seen in the mentioning of her family name, Vibius, ${ }^{34}$ but also in the indication that she is of 'high birth,' that she had an education 'befitting her status' and that she was 'appropriately married' (Shaw 1993:11). It is further mentioned that her father and mother were still alive, that one of her brothers was like she herself a catechumen and that she had a baby son (2.1-3). Her husband is not mentioned, but since her father was still alive she was probably still under his potestas irrespective of whether her husband was still in the picture, depending on whether her marital status was sine manu. ${ }^{35}$ If we take into consideration, the mentioning of her family name as 'Vibius,' the predominant role of the father in the narrative and the absolute silence concerning a husband, the possibility that the father could have belonged to the rather affluent administrative staff which were drawn from the military in service of the provincial governor, and the fact that by $212 \mathrm{CE}$ when universal Roman citizenship was granted (also to the other subjects of the Empire) the notion of patria potestas was in full force, it would be fair to conclude that Perpetua was in potestate of her father. ${ }^{36}$

Her son, though, would have been under the potestas of her husband, and so would have been her slave, Felicitas. Although Perpetua was still under the potestas of her father and therefore still belonged to his household even though married, and although Felicitas belonged to the household of Perpetua's husband, both can be seen 'outsiders' who have entered into the domain of the husband. Parker (1998:154) explains that two distinct groups can be discerned in the Roman familia, namely those that are subject to the father's power by the 'natural bond of blood kinship,' who would be his children, while, slaves and wife would be subject to the father's power only by law. Although "[s]laves and wives differ greatly in power and status, ...they are united by one important factor. Both slaves and wives are brought into the family from outside" (1998:154). Wives, as belonging to the

32 Tertullian's description of the prison as the dwelling place of the devil and the 'invasion' of Christians into this place evokes in inversion the established right of the sanctity of the Roman house, expressed in the perfugium sanctum (a place of shelter), a right also protected by law (cf Saller 1984:350 in particular note 49).

33 See Tertullian who makes 'hindrances ... of the soul' and 'relatives' stop at the prison gate (Ad martyras 2).

34 According to Shaw (1993:10) this was a common name among the military ranks who served in North Africa and were located around Thuburbo Minus. The name 'Vibius' can be seen as an honourable name taken from her father and it distinguished her in two ways - from the slaves in the household who could not carry a second name, and from her husband and children, indicating she derives from another family (see Saller 1998:86)

35 There were two systems that determined the position of women in marriage, and both were expressed in terms of male control. A woman could in marriage be either in manu or sine manu. The former was probably the more original and it refers to a condition where the woman is exchanged from control of her father (who would have been the paterfamilias) to the control of her husband. In this case, she would become legally like a daughter in his house and her dowry would become his. Would her husband die intestate, she would inherit in the same manner as a daughter of the house. The latter refers to a condition where the woman remained under the control of her father, the paterfamilias and his potestas would still be valid for her. In this case whatever she possessed still remains the property of the father until he died in which case she would be sui iuris and would be in control of her own property, albeit often under guardianship. Being sine manu was the trend during the imperial period of the Roman Empire (Skinner 2005:202-203; Treggiari 2003:137-140; Grubbs 1994:364-366; Osiek \& Balch 1997:60-64; Saller 1998:85-86). Since all Roman citizens were subjected to Roman legislature concerning marriage, and since Perpetua's father was clearly a Roman citizen, she would also have been subjected to Roman law.

36 On the widespread and forceful effect of legislation concerning patria potestas, see Arjava (1998). 
group who is under the authority of the husband, would obviously only apply in the case of in manu, because sine manu she and her possessions were beyond the legal control of her husband, which would also imply that by the classical era, familia both in legal and in social discourse, did not include the wife sine manu, but referred to the children and slaves (see Saller 1998:86).

What remains strange is the absence of any mentioning of a husband and yet we are given clues, as if in traces left of what could have been a matrimonial situation. Whether her marriage was in manu or sine manu, her husband by virtue of patria postestas, should have taken her son in his care since he would have belonged to him. Yet in her final encounter with her father, he takes the son away from her and assumes control over him (6.2:7). That implies in effect that the husband was missing, either dead (which is improbable, since she would then have been called a widow), or a situation has emerged where public recognition would have been embarrassing (Osiek 2002:288). According to Osiek (2002), Saturus, who is not mentioned when the arrest takes place, but is only later introduced when her first dream takes place, is prime candidate to be her husband. Reference is made to his appearance in crucial sections of the narrative, the decisive role he plays in these episodes $(2002: 290),{ }^{37}$ his closeness to Perpetua and the centrality in his dreams $(2002: 288,289,290) .{ }^{38}$ Although Osiek submits a thesis of probable embarrassment which could either be related to Saturus himself and his late appearance in the narrative, or to the circulation of the narrative under Perpetua's name, she leaves the question open with the following apt conclusion: "Embarrassment about Saturus on the part of the community is speculation, but something about him is deliberately left unstated. Saturus may have been more a part of Perpetua's life than meets the eye" (2002:290).

There is, however, one possibility Osiek also mentions but discards. It concerns the use of familial discourse within the framework of the spectacle. On the day of their torturing, while on the way to the theatre, Perpetua is described as matrona Christi (wife of Christ) and Dei delicata (darling of God, 18.2). Also using familial discourse, but even with more deliberation is the description of Felicitas (18.3). Mention is first made of her daughter's birth and then her entry into the amphitheatre is described as a sanguine ad sanguinem, ab obstetrice ad retiarum $^{39}$ (from blood to blood, from midwife to retarius), lotura post

37 For example: he is the first to ascend the ladder in the first vision; he warns Perpetua concerning the dragon (Perp. Felicit. 4.5); the presentation of his own vision (11.2-13.8)

38 For example: just as he preceded Perpetua in ascending the ladder, he is killed by the sword before her (21.8); in the vision of Saturus, they are the two main characters from beginning to end (11.2-13.8); in the vision it is Saturus who specifically mentions that Perpetua is at his side (11.4), they mutually share the admiration of the angels (11.7), together they meet the 'aged man'(12.2-5); together they are mandated to participate in the games (12.6). Without mentioning in any way any form of marital relationship, it is indeed as if the narrator deliberately establishes a special relationship between them. Even within the amphitheatre, a remarkable similarity is maintained. The first attempt to tie Saturus to a wild boar did not succeed, just as the unwillingness of the bear even to approach him (19.4-6); in a similar manner the mad cow did not succeed in killing Perpetua and Felicitas (20.1-10). So just as in the case with Saturus, they were returned to the gates of the amphitheatre. There Perpetua talked to a Rusticus and to her brother (20.8-10 whereas at another gate, Saturus was talking to the soldier Pudens first mention is made of Saturus, Saturninus and Revocatus being led into its space), and in both cases they encouraged steadfastness in faith. Then it is the final scene, where Saturus's throat is cut which is followed by Perpetua who had to guide the young gladiator's hand to her throat (21.7-10).

39 Although the obstetrix could also assist medically beyond the range of childbirth, her identity was specifically related to the process of birth, and must consequently be distinguished from other categories of female medical practitioners (see Flemming 2000:36-42). The retiarius is a particular role belonging to the gladiatorial family, whose identity is constituted by his specific armour, namely a trident and a net. He did not wear a helmet, greaves, or carry a shield and owing to his specific armoury could easily be distinguished from other 
partum baptismo secundo (on the verge to wash after childbirth with a second baptism, 18.3). According to Osiek, the terminologies used in the case of Perpetua, such as matrona and delicata are household, but not 'spousal language' (2002:289), assigning ecclesial dignity to her. Whether such a distinction should be made is disputable, but even if, it does not in any way prevent that Saturus was married to Perpetua.

It was in Carthage during more or less the same period, that a Tertullian, instructing her on widowhood (Tert. Ux. 3), wrote to his wife. Several different issues are addressed, but the basic tendency that is addressed is the control and management of desire. Paul's advice is the point of departure for constructing marriage as a site where desire is to be dealt with. Owing to this 'contamination' marriage is negatively valorized and regarded as the inferior option. It is allocated to the domain of the permissible, but not preferable; marriage is granted on the basis of necessity, "but whatever necessity grants, she by her very nature depreciates" (Tert. Ux 3). Interpreting the Pauline "it is better to marry than to be aflame with passion" (1 Cor 7:9) he illustrates his skill in analysing a rhetorical argument. He points to the fact that the comparison made by Paul, ranks marriage with what can be regarded as evil, thereby lessening the value of marriage (Tert. Ux. 3). ${ }^{40}$ Even though marriage may be seen as permissible, and even though it may be seen as the site for legitimate desire, the tendency towards the exclusion of desire can be seen in an underlying prompting towards abstinence even within marriage (see for example $U x .6$ ). Decreasing the value of marriage continues when offspring is problematised in light of the time they are in and he advises that "they who have wives act as if they had them not" $(U x .5)$. Although this tendency towards the denigration of the of marriage as social institution, which we know was widespread beyond the range of the Tertullian oeuvre in early Christianity, is not conclusive evidence for deciding the question of whether Saturus was Perpetua's husband it could be argued that the omission of it functions to shift to the background what was regarded as an 'encumbrance,' as not a preferable option in a time when consolidation became increasingly compelling.

So, while a matrimonial relationship between Saturus and Perpetua is given no status, a matrimonial relationship between Perpetua and Christ is foregrounded. Roman familial discourse is appropriated by early Christian religious discourse. She has indeed become matrona in the household of Christ. Saturus must recede to the background - although he is sometimes explicitly foregrounded, his role is that of sustaining, supporting Perpetua. ${ }^{41}$ Tertullian's voice again echoes in the background, advising his wife to emulate those

members of the gladiatorial family (Junkelmann 2000:59-61). Why this specific type of gladiator was used in this case is not certain. Rumour would have it that the emperor Claudius had every defeated retarius killed since the agony of the dying man could more visibly be seen and experienced in the case of the retarius because, not wearing any helmet, their faces were exposed (Auguet 1994:49). Could the use of retarius here be an allusion to the painfulness of death in the amphitheatre?

40 Elaborating and explaining the ranking of features between what is compared, he refers to the use of another comparison, namely that it is better to flee than to deny the faith when arrested. He argues that what is permitted is tainted by some component of suspicion deriving from what is prohibited.

41 In the first vision it is explicitly mentioned that he first (prior) ascended the ladder (4.5); it is conceded by Perpetua herself that 'he himself had built us up' (4.5); when he arrived at the top of the ladder, he turned back to assure Perpetua that he sustains or supports her (Musurillo's translation 'I waiting for you...' does not really make sense); to this incident is again referred in 21.8 when he also leads the way in death and again his support for Perpetua is referred to. In Saturus's own vision, he constantly interprets what is happening and conveys that to Perpetua (see $11.4 ; 12.7$ ), and in 14.1 he is mentioned before Perpetua. Having their last meal before their appearance in the amphitheatre, Saturus is the only one addressing the mob (17.1). There appears to be a tension in his character; on the one hand, deliberately foregrounded and assuming leadership; on the other hand, supportive, holding back, almost being restrained. 
'sisters of ours' whose husbands have already passed away and who have consequently wedded themselves to God. Their marriage to God dissolves the boundary between the human and the divine, as they "are already counted and empowered as belonging to the angelic family" (Ux. 4). It could be argued, that if Saturus were known by the audience(s) of this narrative, and if it were known that Perpetua and Saturus were married, the deliberate omission of marital relations increases the focus on the family of Christ. The family of Christ is what is 'presentified,' it is given prominent presence by the very absence of what can only be regarded as a necessity for the curbing of desire, and Perpetua is to be lifted and respected within a position of status in the family of Christ, that equals not only the status of matrona, but that of domina (4.1:5.5). Familial discourse embedded within the discourse of spectacle functions to achieve this 'social' elevation.

As matrona, Perpetua responds to what was typically required of her role. She is firstly the loyal 'wife' whose fides (loyalty) is such that she is willing to be sacrificed on behalf of her husband's interests. If her husband were indeed Saturus and if the audience were acquainted with their relationship, there could have been no doubt that she was indeed the loyal wife, identifying with a shared purpose and goal, sharing the same interests and accompanying her husband, not only in the agony of suffering, but also in death. This is, however, not the level on which her loyalty was portrayed. The narrative portrays Perpetua as the loyal wife of Christ. Parker (1998) has indicated to what extent the loyal wife functioned as exemplum in the Roman world. Characteristic of the loyal wife is that she not only fulfills matrimonial obligations, that is, her official role as matrona, but that she acts to the benefit (beneficium) of her husband. It is the wife who transforms officium (duty) into beneficium who can be seen as the real matrona. She exists to bring honour and dignity to the household of her husband. Hanson (1999:35) writes: "Her virtues and her unswerving seriousness of purpose (gravitas) were modelled on those of her husband in his conduct of public business." In a patriarchal society where a woman is defined in terms of a man, a wife's role implies amalgamating with her husband, becoming like her husband, appropriating his superior masculinity, becoming 'man,' as can indeed be seen by Perpetua's gender-transformation in her combat with the Egyptian (10.7). Proof of excelling beyond the expected is to follow the husband in exile, to assist the husband in suicide or commit suicide with him when permitted by the husband, and/or to suffer torture with or on behalf of the husband. Perpetua leaves the safe environment her father's potestas offers her ${ }^{42}$ and is imprisoned owing to her loyalty to Christ. ${ }^{43}$ When she is asked to sacrifice 'for the welfare of the emperors,' she refuses to betray Christ, just as she refuses to don the clothes of Ceres priestesses (18.4), an act characterising her as generosa illa, 'that woman of noble birth.' Her ultimate act of loyalty arrives when the failed execution turns into a suicide, a self-sacrifice, when she guides the trembling hand of the gladiator to her throat. The comment that her voluntariness exhibits her as a woman that is great and courageous $(21.10$; see also 18.5) demonstrates her loyalty as domina within the household of Christ. This was seen as the ultimate of a wife's loyalty (Treggiari 2003:182; Parker 1998:167).

42 There is the possibility that even the self-entitlement as christiana, especially in confrontation with her father, may signify her loyalty, her fides towards Christ, especially since she was probably in terms of law under the potestas of her father (3.2); also at her trial where the presence of her father is again evoked (6.4).

43 One should at the same time also see how the relationship with Saturus is also casted into the mould of the loyal wife. When we encounter Saturus for the first time in the first vision, Perpetua follows him up the ladder despite of danger lurking on the way (4.5-6). This is not exile, suicide or torture, and loyalty is not explicitized, but the element of trusting and following should not be discarded. 
It is her indubitable loyalty to him which grants her to be promoted to the status of domina. The term domina signified a position of status and respect within the hierarchy of the houshold - basking in the aura of the dominus, domina gives expression to a position of power in familial hierarchy. In tending to the interests of her husband, in bestowing glory on the husband via her loyalty, the matrona has earned the position of domina in relation to the other members of the household. The play between her brother's address to her as domina soror ('lord' sister, 4.1) and her response to talk to the 'lord' (dominus) signifies the position she has come to occupy within the household of God. ${ }^{44}$ Her elevation to this position of status is also signified in her second confrontation with her father (5.1-6). He first addresses her as filia (daughter, 5.2) and there is the allusion to his potestas over her in his reference to the favourable conditions that brought her to the 'prime of life' (5.2); ${ }^{45}$ he did what was socially expected of him as the paterfamilias, he gave expression to his pietas (dutifulness, 5.5), ${ }^{46}$ that to which he is socially obliged to guard (see Jacobs 2003; Treggiari 2003:179,181). However, within this encounter his form of address moves from filia to domina when Perpetua mentions "that he no longer called me daughter, but 'domina' (5.5)." ${ }^{, 47}$ Her response to him that "we are no longer constituted in our potestas, but in God's" (5.6) indicates that household discourse functions as the context within which Perpetua's position should be seen as domina. While availing herself of the normative, cultural household terminology expressing particular social hierarchies within the household, an alternative order is proposed, which did not reject the traditional but offered the possibility of a redefinition, but then a redefinition fuelled and determined by the valuesystem underlying Roman domestic discourse.

Several aspects which cannot here be fully demonstrated confirm that domestic discourse embedded within spectacle discourse functioned subservient to the ideals of phallocraticism, placating the threat of female uncontrollability the emerging movement may cultivate, while simultaneously suggesting a radicalization of normative Roman culture. Claiming this superiority can also be seen in the demonstration of Perpetua's pudicitia (20.4), as well as her apparent resistance to her father's potestas, which should not be taken as a rejection, but rather as transference of this power to Christ and by extension to the leaders of the church. It can also be seen in the portrayal of Felicitas who is 'kept in place' by scant attention paid to her, by her passive predisposition, by the birth of her daughter and the allocation to the sisters. That the hidden script of this writing serves phallocraticismcan also be seen by the predominance of males ${ }^{48}$ and, except for Perpetua and

44 See also how she is further qualified by her brother as 'iam in magna dignatione es' (you are already in great esteem, 4.1).

45 See the use of manus in manibus as a reference to his authority as head of the household in which she was born.

46 The translation in Musurillo (1972:113), 'out of love for me' infuses pietas with $20^{\text {th }}$ century personalised affection - there is more at stake in this section.

47 The translation 'as a woman' (Musurillo 1972:113) still clings to the highly personalised, affectionate, almost oedipean, contemporary relationship between a dad and his little daughter, which is not what is signified in this context.

48 For example: the addressees in the introductory section (1.6), the father $(2.2 ; 3.1-4 ; 5.1-6 ; 6.2-5,7 ; 9,2-3)$, her brothers $(2.2 ; 4.1-2,10 ; 7.1-8.4)$; Saturus $(4.5-6 ; 11.1-13.8 ; 14.1 ; 17.1 ; 18.7 ; 19.4-5 ; 21.1-8)$, co-martyrs such as Saturninus $(2.1 ; 18.7 ; 19.2)$ and Secundulus $(2.1 ; 14.2)$, Revocatus $(2.1 ; 18.7 ; 19.2)$, deacons or helpers, Tertius and Pomponius (3.7), Pomponius (10.1-4), Rusticus (20.8), grey-haired old man (4.9) who addresses Perpetua, the matrona as 'child'; the trainer (10.11) who addresses her as 'daughter'; the bishop and presbyter (13.1-6) and then Roman officials and soldiers, such as Hilarianus (6.3-7), Pudens (21.1:4-6). 
Felicitas, the shadowy existence of women, such as Perpetua's mother and one of the sisters $(15.7)^{49}$

\section{Conclusion}

Although the discursive practice of the household and the discursive practice of the spectacle may appear to be unrelated and discrete, an enquiry into some of martyr narratives, indicate that an intercalating relationship exists. Domestic discourse is extensively used within spectacle and martyr discourse, and requires further examination. The intercalating relationship between martyr and domestic discourse simultaneously also confirm how both were not only the product of, but also contributed to the construction of the public sphere during the Roman imperial period.

Early Christian identity was not shaped in a vacuum, but emerged and was configured from a complex web of power relations, institutions, values and norms, deriving from an already pre-packaged Hellenistic world. Burrus (2005) writes: "From the perspective of hindsight inevitably refracted through the lens of more recent experiences of empire and colonization, the ancient Mediterranean terrain unfurls as a scarred surface, layered with histories of conquest and traversed by passages between cultures only knowable as such retrospectively and problematically, in the moment of their mutual, agonistic differentiation - in the moment when purity is already 'lost.' She then uses a model of 'hybriditization' (2005:51) in an analysis of selected ancient romances, to demonstrate how culturally constructed forces 'collide and collude"" $(2005: 50,56)$. The same experience is evoked when martyr discourses are embedded within the Graeco-Roman world and approached from the perspective of the domus. Dominant patriarchal-normative Roman culture, with its insistence on a relentless phallocratic ethos, sets the parameters and offers the repertoire within which 'collisions' may be made.

The use of domestic discourse within the framework of spectacle discourse did not domesticate the arena, but functioned as a strategic mechanism to illustrate early Christian moral and bodily superiority. Evoking the suggestion of kinship proximity, of stability and fixity, of maintaining social hierarchies, and stretching Roman regulatory ideals to its limits, it also functioned to project early Christians as beneficial to society, and as a constituent component in the making of dignitas, despite of the misrecognition of those in power.

49 It would also be possible to elaborate on Perpetua's status as domina with reference to her pudicitia (modesty), an essential component of a wife's pietas, referring to her sexual integrity (20.2; also Treggiari 2003:179). It would also be possible to elaborate on Perpetua's encounters with her father, which may at first appear to be a rejection of the patriarchal potestas. However, potestas as such is not subjected to a critique by these encounters - it is transferred to another male, namely Christ, and by extension the male leaders of the emerging church. 


\section{BIBLIOGRAPHY}

Arjava, Antti 1998. Paternal Power in Late Antiquity. The Journal of Roman Studies 88:147-165.

Auguet, Roland 1972. Cruelty and Civilization: The Roman Games. London: Routledge.

Bergmann, Bettina 1999. Introduction: The Art of Ancient Spectacle. Pages 9-35, in The Art of Ancient Spectacle. Edited by Bergmann, Bettina and Kondoleon, Christine. Washington: National Gallery of Art.

Bomgardner, David L 1989. The Carthage Amphitheater: A Reappraisal. American Journal of Archaeology 93:85-103.

Brown, Shelby 1992. Death as Decoration: Scenes from the Arena on Roman Domestic Mosaics. Pages 180-211 in Pornography and Representation in Greece and Rome. Edited by Richlin, A Oxford: Oxford University Press.

Burrus, Virginia 2005. Mimicking Virgins: Colonial Ambivalence and the Ancient Romance. Arethusa 38:49-88.

Carson, Anne 2002. Dirt and Desire: The Phenomenology of Female Pollution in Antiquity. Pages 77-100, in Constructions of the Classical Body. Ann Arbor: University of Michigan Press.

Cooper, Kate 2007. Approaching the Holy Household. Journal of Early Christian Studies 15(2):131-142.

Callahan, Allen D 1998. Slave Resistance in Classical Antiquity. Semeia 83/84:133-151.

Flemming, Rebecca 2000. Medicine and the Making of Roman Women: Gender, Nature, and Authority from Celsus to Galen. Oxford: Oxford University Press.

Gaca, Kathy L 2003. The Making of Fornication: Eros, Ethics, and Political Reform in Greek Philosophy and Early Christianity. Berkeley: University of California Press.

Grubbs, Judith E 1994. 'Pagan' and 'Christian' Marriage: The State of the Question. Journal of Early Christian Studies 2(3):361-412.

Gleason, Maud W 2002. Truth Contests and Talking Corpses. Pages 287-313, in Constructions of the Classical Body. Edited by Porter, James I. Ann Arbor: Michigan Press.

Hales, Shelley 2000. At Home with Cicero. Greece \& Rome 47(1):44-55.

Hanson, Anne 1999. The Roman Family. Pages 1-66, in Life, Death, and Entertainment in the Roman Empire. Edited by Potter, DS and Mattingly, DJ Ann Arbor: The University of Michigan Press.

Harvey, Susan A 2006. Scenting Salvation: Ancient Christianity and the Olfactory Imagination. Berkeley: University of California Press.

Hopkins, Keith 1983. Death and Renewal. Vol.2. Sociological Studies in Roman History. Cambridge: Cambridge University Press.

Jacobs, Andrew A 2003. 'Let Him Guard Pietas': Early Christian Exegesis and the Ascetic Family. Journal of Early Christian Studies 11(3):265-281.

Junkelmann, Marcus 2000. Familia Gladiatoria: The Heroes of the Amphitheatre. Pages 31-74, in The Power of Spectacle in Ancient Rome: Gladiators and Caesars. Edited by Kohne, Eckart and Ewigleben, Cornelia. London: British Museum Press.

Middleton, Paul 2006. Radical Martyrdom and Cosmic Conflict in Early Christianity. London: T\&T Clark. 
Musurillo, Herbert 1972. The Acts of the Christian Martyrs. Oxford: Clarendon Press.

Osiek, Carolyn and Balch, David I 1997. Families in the New Testament World Households and House Churches. Louisville: Westminster John Knox Press.

Osiek, Carolyn 2002. Perpetua's Husband. Journal of Early Christian Studies 10(2): 287-290.

Parker, Holt 1998. Loyal Slaves and Loyal Wives: The Crisis of the Outsider-within and Roman exemplum literature. Pages 152-173, in Women and Slaves in Greco-Roman Culture. Edited by Joshel, Sandra R and Murnaghan, Sheila. New York: Routledge.

Parker, Holt 1999. The Observed of All Observers: Spectacle, Applause, and Cultural Poetics in the Roman Theatre Audience. Pages 163-179, in The Art of Ancient Spectacle. Edited by Bergmann, Bettina and Kondoleon, Christine. Washington: National Gallery of Art.

Potter, David S 2002. Odor and Power in the Roman Empire. Pages 169-189, in Constructions of the Classical Body. Edited by Porter, James I. Ann Arbor: University of Michigan Press.

Ronsse, Erin 2006. Rhetoric of Martyrs: Listening to Saints Perpetua and Felicitas. Journal of Early Christian Studies 14(3):283-327.

Saller, Richard P 'Familia, Domus', and the Roman Conception of Family. Phoenix 38(4):336-355.

Saller, Richard P 1998. Symbols of gender and status hierarchies in the Roman household. Pages 85-91 in Women and Slaves in Greco-Roman Culture: Differential equations. Edited by Joshel, Sandra R \& Murnaghan, Sheila. London and New York: Routledge.

Shaw, Brent 1993. The Passion of Perpetua. Past \& Present 139:3-45.

Skinner, Marilyn B 2005. Sexuality in Greek and Roman Culture. Malden: Blackwell. Treggiari, Susan 2003. Marriage and Family in Roman Society. Pages 132-239, in Marriage and Family in the Biblical World. Edited by Campbell, Ken M Downers Grove: Intervarsity Press.

Wypustek, Andrzej 1997. Magic, Montanism, Perpetua, and the Severan Persecution. Vigiliae Christianae 51(3):276-297. 